\title{
Pemahaman Siswa Kelas XI SMA Unggulan Kota Padang Terhadap Konsep Reaksi Pengendapan pada Pembelajaran Materi Kelarutan dan Hasilkali Kelarutan
}

\author{
Monica Prima Sari ${ }^{1)}$, Hernani $^{2}$, Sri Mulyani ${ }^{3)}$ \\ ${ }^{1)}$ Jurusan Pendidikan IPA, Universitas Negeri Padang \\ ${ }^{2)}$ Jurusan Kimia, Universitas Pendidikan Indonesia \\ ${ }^{3)}$ Jurusan Kimia, Universitas Pendidikan Indonesia \\ email: primasarimonica@fmipa.unp.ac.id
}

\begin{abstract}
This paper describes $11^{\text {th }}$ grade students' understanding of the concept of precipitation reaction at the end of the learning process of solubility and solubility product. Precipitation reaction is an important reaction in industry, pharmacy, and daily life. In the learning process, students are asked to predict the formation of precipitation based on their understanding of solubility and solubility product concepts. Thirty eleventh grade students in one of the best senior high schools in Padang were chosen as the subject of this study. Classroom learning process was observed and recorded. Data of students' understanding were collected through a set of essay problems which was validated through expert judgment, and then integrated in students' end-of-chapter test. Through qualitative analysis, this study revealed some mistakes and misconceptions that students have regarding the application of precipitation reaction concept, and possible sources of them. Recommendations for improving the quality of learning this concept in the future are provided at the end of the paper.
\end{abstract}

Keywords : Students' understanding, Precipitation reaction, Solubility, Solubility product.

is is an open access article distributed under the Creative Commons 4.0 Attribution License, which permits unrestricted use, distribution, and reproduction in any medium, provided the original work is properly cited. $\odot 2018$ by author and Universitas Negeri Padang.

\section{PENDAHULUAN}

Reaksi pengendapan merupakan salah satu reaksi yang sangat penting dalam dunia industri, obat-obatan, dan kehidupan sehari-hari. Baking soda (natrium bikarbonat) yang umum digunakan dalam industri makanan, peristiwa pelarutan enamel gigi (tersusun dari mineral hidroksiapatit, $\left.\left[\mathrm{Ca}_{3}\left(\mathrm{PO}_{4}\right)_{3} \mathrm{OH}\right]\right)$, dan penggunaan Barium Sulfat untuk mendeteksi penyakit akibat gangguan sistem pencernaan adalah beberapa contoh dari penerapan reaksi pengendapan (Chang, 2008).

Reaksi pengendapan menghasilkan produk berupa senyawa tak larut (endapan), yang pembentukannya bergantung pada kelarutan senyawa ionik yang diharapkan mengendap (Chang, 2008). Terkait dengan kelarutan ini, para ahli kimia membagi kelarutan dalam beberapa tingkat, yaitu: "larut", "sedikit larut" dan "tak larut". Yang perlu digarisbawahi adalah bahkan senyawa yang dikategorikan "tak larut" sekalipun pada dasarnya tetap dapat larut, hanya saja dalam jumlah tertentu yang sangat sedikit.

Dalam kurikulum mata pelajaran Kimia untuk SMA, konsep reaksi pengendapan terdapat dalam materi Kelarutan dan Hasilkali Kelarutan yang dipelajari siswa di kelas IX. Seperti halnya konsep-konsep lain dalam mata pelajaran Kimia SMA, kompetensi yang diharapkan dapat dicapai siswa adalah mampu menganalisis dan menyelesaikan permasalahan yang berkaitan dengan sifat molekul, kesetimbangan kimia, reaksi kimia, kinetika kimia dan energetika, serta menerapkan pengetahuan ini pada berbagai bidang ilmu dan teknologi (Kemendikbud, 2016). Secara lebih spesifik, untuk materi Kelarutan dan Hasilkali Kelarutan, kompetensi dasar yang diharapkan dicapai siswa adalah mampu memprediksi terbentuknya endapan dari suatu reaksi berdasarkan prinsip kelarutan dan hasilkali kelarutan. Prediksi ini lebih menekankan aspek termodinamika karena fokus kepada produk yang akan terbentuk, bukan pada aspek kinetika (Harris, 2010). Pencapaian kompetensi ini bergantung pada pemahaman siswa terhadap konsep-konsep relevan yang telah dipelajari sebelumnya, yaitu: konsep mol, massa atom relatif, persamaan reaksi, kesetimbangan kimia, serta konsentrasi larutan.

Keterkaitan konsep reaksi pengendapan dalam materi kelarutan dan hasilkali kelarutan dengan banyak konsep kimia lainnya merupakan salah satu alasan mengapa materi ini dianggap sulit oleh siswa. Meski mata pelajaran kimia berisi berbagai fenomena dan aktivitas percobaan menarik serta pengetahuan yang ber- 
manfaat untuk memahami dunia (Chiu, 2005), kimia merupakan mata pelajaran yang tidak populer di kalangan siswa (Holbrook, 2005). Salah satu penyebabnya adalah banyaknya konsep yang sulit dipahami siswa (Sheehan, 2010), yang sifatnya abstrak sehingga mengharuskan siswa untuk meluangkan waktu khusus dalam berusaha memahaminya (Wu dan Foos, 2008).

Pada dasarnya, konsep-konsep dalam ilmu kimia memiliki tiga level representasi, yaitu: makroskopis, simbolis, dan submikroskopis (Johnstone, 2000). Penguasaan terhadap konsep kimia mengharuskan siswa untuk memiliki pemahaman yang memadai pada setiap level rep- resentasi dan menghubungkan ketiga level tersebut untuk membangun pengetahuan dalam dirinya (Nakhleh dan Hinton, 1999). Secara tersirat dapat dipahami bahwa mata pelajaran kimia hanya menarik bagi siswa yang mampu berpikir kompleks, yang mampu menghubungkan pemahaman mereka pada setiap level representasi konsep kimia.

Berdasarkan uraian di atas, penulis melakukan penelitian di salah satu sekolah unggulan kota Padang untuk menggali pemahaman siswa terhadap konsep reaksi pengendapan dalam materi kelarutan dan hasilkali kelarutan. Penelitian ini difokuskan pada kemampuan siswa dalam menerapkan pemahaman mereka terhadap konsep kelarutan untuk memprediksi pembentukan endapan, yang merupakan kompetensi dasar dari materi ini. Selain itu, penelitian ini juga bertujuan untuk menemukan miskonsepsi, konsepsi alternatif siswa atau bentuk kesalahan siswa dalam menerapkan pemahamannya terkait konsep reaksi pengendapan.

\section{METODE PENELITIAN}

Penelitian ini merupakan bagian dari penelitian yang lebih besar mengenai keterkaitan proses pembelajaran dengan pemahaman siswa terkait konsep-konsep dalam materi kelarutan dan hasilkali kelarutan. Berhubung peneliti ingin mendapatkan pemahaman siswa tanpa intervensi khusus dari pihak lain (murni hanya dari guru dan proses pembelajaran), maka peneliti menerapkan strategi naturalistic inquiry. Strategi ini menekankan kealamiahan setting penelitian tanpa manipulasi apapun dari peneliti, dan temuannya disajikan sesuai keadaan sebenarnya tanpa dilebih-lebihkan (Basrowi dan Suwandi, 2008).
Subyek dalam penelitian ini berjumlah 30 siswa yang ditentukan berdasarkan kesediaan guru untuk mengizinkan kelasnya diobservasi. Data utama dalam penelitian ini adalah pemahaman siswa, yang diperoleh dengan instrumen tes essay, yang sesuai untuk menggali pemahaman siswa yang sifatnya cukup kompleks (Gronlund dan Linn, 1990). Untuk menghindari bias, penyusunan tes ini tidak melibatkan guru yang mengajar kecuali saat peneliti mengkonsultasikan kompetensi dasar dan indikator ketercapaian pembelajaran. Validasi instrumen tes essay dan rubrik penilaiannya dilakukan dengan cara expert judgement dengan melibatkan tiga orang dosen kimia dan empat guru kimia SMA. Soal yang telah divalidasi kemudian diintegrasikan ke dalam soal ulangan harian siswa untuk materi kelarutan dan hasilkali kelarutan.

Instrumen tes essay yang digunakan untuk menggali pemahaman konsep siswa terhadap konsep reaksi pengendapan dapat diperhatikan pada Tabel 1.

\section{Tabel 1. Instrumen Tes Essay Konsep Reaksi Pengendapan}

\begin{tabular}{|c|c|c|}
\hline No. & \multicolumn{2}{|c|}{ Butir soal } \\
\hline \multirow[t]{8}{*}{1.} & \multicolumn{2}{|c|}{ Diketahui nilai $K_{s p}$ senyawa garam sulfat berikut. } \\
\hline & Senyawa elektrolit & $K_{s p}$ \\
\hline & $\mathrm{CaSO}_{4}$ & $2,4 \times 10^{-5}$ \\
\hline & $\mathrm{SnSO}_{4}$ & $2,5 \times 10^{-7}$ \\
\hline & $\mathrm{BaSO}_{4}$ & $1,1 \times 10^{-10}$ \\
\hline & $\mathrm{HgSO}_{4}$ & $6,7 \times 10^{-7}$ \\
\hline & $\mathrm{PbSO}_{4}$ & $1,7 \times 10^{-8}$ \\
\hline & \multicolumn{2}{|c|}{$\begin{array}{l}\text { Jika satu liter larutan garam sulfat mengandung ion } \\
\mathrm{Ca}^{2+}, \mathrm{Sn}^{2+}, \mathrm{Hg}^{2+}, \mathrm{Ba}^{2+} \text { dan } \mathrm{Pb}^{2+} \text { dengan konsentrasi } \\
\text { yang sama, kemudian larutan tersebut ditetesi laru- } \\
\text { tan } \mathrm{Na}_{2} \mathrm{SO}_{4} \text { maka tentukanlah urutan senyawa } \\
\text { garam tersebut mulai dari yang pertama mengen- } \\
\text { dap. Kemukakan alasanmu yang mendasari penen- } \\
\text { tuan urutan tersebut. }\end{array}$} \\
\hline 2. & \multicolumn{2}{|c|}{$\begin{array}{l}\text { Seorang siswa diminta menyiapkan } 0,5 \mathrm{~L} \text { larutan } \\
\text { yang mengandung } 0,0075 \text { mol } \mathrm{NaCl} \text { dan } 0,075 \text { mol } \\
\mathrm{Pb}\left(\mathrm{NO}_{3}\right)_{2} \text {. Mengingat bahwa senyawa timbal klor- } \\
\text { ida sukar larut dalam air, siswa tersebut mempred- } \\
\text { iksi bahwa endapan akan terbentuk. Buktikanlah } \\
\text { prediksi siswa tersebut jika } K_{\mathrm{sp}} \mathrm{PbCl}_{2} \text { diketahui } \\
\text { bernilai } 1,7 \times 10^{-5} \text {. }\end{array}$} \\
\hline
\end{tabular}

Untuk melihat keterkaitan pemahaman siswa dengan proses pembelajaran yang dilalui, peneliti melakukan observasi pembelajaran sebagai complete observer. Untuk kepentingan pengumpulan dan analisis data, setiap pertemuan terkait konsep reaksi pengendapan direkam kemudian ditranskripsikan. 
Data pemahaman siswa bersifat kualitatif, oleh sebab itu peneliti memilih menggunakan teknik analisis data kualitatif. Teknik ini mencakup kegiatan mengorganisasikan data, memilah dan mengelola data, mensintesis, mencari pola, menemukan apa yang penting dari data, dan mengambil keputusan (Bogdan dan Baiken dalam Basrowi dan Suwandi, 2008). Melalui analisis horizontal, peneliti mengelompokkan pemahaman siswa ke dalam 6 derajat pemahaman yang dikembangkan oleh Abraham, Grzybowski, Renner, dan Marek, (1992), yang mencakup: memahami konsep, memahami sebagian, memahami sebagian dengan miskonsepsi, miskonsepsi, tidak memahami, dan tidak ada jawaban seperti ditampilkan pada Tabel 2 .

Tabel 2. Kategori Pemahaman Siswa (Abraham, R. Michael, dkk., 1992)

\begin{tabular}{|c|c|c|c|}
\hline No. & Kriteria & $\begin{array}{c}\text { Tingkat } \\
\text { Pemahaman }\end{array}$ & $\begin{array}{c}\text { Kategori } \\
\text { Pema- } \\
\text { haman }\end{array}$ \\
\hline 1. & $\begin{array}{l}\text { Tidak ada jawaban/ kosong, menjawab } \\
\text { saya tidak tahu. }\end{array}$ & $\begin{array}{c}\text { Tidak ada } \\
\text { respon }\end{array}$ & \multirow{2}{*}{$\begin{array}{l}\text { Tidak } \\
\text { Me- } \\
\text { mahami }\end{array}$} \\
\hline 2. & $\begin{array}{l}\text { Mengulang pernyataan, menjawab tapi } \\
\text { tidak berhubungan dengan pertanyaan } \\
\text { atau tidak jelas. }\end{array}$ & $\begin{array}{c}\text { Tidak } \\
\text { memahami }\end{array}$ & \\
\hline 3. & $\begin{array}{l}\text { Menjawab dengan penjelasan tidak } \\
\text { logis. }\end{array}$ & Miskonsepsi & \multirow[b]{2}{*}{ Miskonseps } \\
\hline 4. & $\begin{array}{l}\text { Jawaban menunjukkan ada konsep } \\
\text { yang dikuasai tetapi ada pernyataan } \\
\text { yang menunjukkan miskonsepsi. }\end{array}$ & $\begin{array}{c}\text { Memahami } \\
\text { sebagian } \\
\text { dengan } \\
\text { miskonsepsi }\end{array}$ & \\
\hline 5. & $\begin{array}{l}\text { Jawaban menunjukkan hanya sebagian } \\
\text { konsep dikuasai tanpa ada miskonsepsi. }\end{array}$ & Miskonsepsi & \multirow{2}{*}{ Memahami } \\
\hline 6. & $\begin{array}{l}\text { Jawaban menunjukkan konsep dipa- } \\
\text { hami dengan semua penjelasan benar. }\end{array}$ & $\begin{array}{c}\text { Memahami } \\
\text { konsep }\end{array}$ & \\
\hline
\end{tabular}

Keenam derajat pemahaman untuk setiap soal tes telah divalidasi melalui experts judgement. Temuan penelitian berupa kesalahan siswa dalam menjawab soal dan konsepsi alternatif, digunakan untuk merefleksi proses pembelajaran dan menjadi dasar bagi peneliti untuk merumuskan rekomendasi untuk meningkatkan kualitas pembelajaran konsep reaksi pengendapan di masa yang akan datang.

\section{HASIL DAN PEMBAHASAN}

\section{Pemahaman Siswa terhadap Konsep Reaksi Pengendapan}

Untuk menjawab soal pertama, siswa harus memahami bahwa endapan garam sulfat akan terbentuk jika hasilkali konsentrasi ion-ion dalam larutan $\left(Q_{\mathrm{c}}\right)$ lebih besar dari nilai $K_{\mathrm{sp}}$-nya masing-masing. Kelima kation dalam larutan garam sulfat diketahui memiliki konsentrasi dan koefisien yang sama dalam persamaan reaksi setimbangnya. Dengan demikian, ketika ditambahkan larutan $\mathrm{Na}_{2} \mathrm{SO}_{4}$, nilai $K_{\text {sp }}$ yang terlampaui lebih dahulu adalah yang terkecil, kemudian diikuti nilai yang lebih besar. Dari soal, nilai $K_{\text {sp }}$ terkecil dimiliki oleh $\mathrm{BaSO}_{4}$, yaitu $1,1 \times 10^{-10}$. Oleh karena itu, ketika ditambahkan larutan $\mathrm{Na}_{2} \mathrm{SO}_{4}$, yang mula-mula mengendap adalah $\mathrm{BaSO}_{4}$, diikuti $\mathrm{PbSO}_{4}, \mathrm{SnSO}_{4}, \mathrm{HgSO}_{4}$, dan terakhir $\mathrm{CaSO}_{4}$.

Seperti halnya dalam menjawab soal pertama, soal kedua juga menuntut siswa untuk memahami bahwa endapan akan terbentuk jika nilai $Q_{\mathrm{c}}$ lebih besar dari $K_{\mathrm{sp}}$. Karena nilai $K_{\mathrm{sp}}$ $\mathrm{PbCl}_{2}$ sudah diketahui dari soal, maka yang harus dilakukan siswa adalah menghitung nilai $Q_{\text {c }}$. Perhitungan nilai $Q_{\mathrm{c}}$ memerlukan konsentrasi molar dari ion-ion $\mathrm{PbCl}_{2}$. Jadi, benar tidaknya jawaban siswa untuk soal ini bergantung pada kebenaran perhitungan yang dilakukan dan prediksi berdasarkan hasil perhitungan tersebut.

Untuk soal pertama, kriteria jawaban siswa yang termasuk kategori memahami konsep adalah jika urutan garam sulfat dari yang lebih dulu hingga yang terakhir mengendap benar, dasar atau alasan penentuannya benar, dan menyinggung fakta bahwa koefisien ion dalam reaksi setimbang dan konsentrasi semua garam sama. Sementara untuk soal kedua, kriteria jawaban yang dinyatakan memahami konsep adalah jika pernyataan prediksi dan dasar prediksi pembentukan endapan benar, yaitu perbandingan nilai $Q_{\mathrm{c}}$ dengan $K_{\mathrm{sp}}$, serta didukung hasil perhitungan yang menunjukkan bahwa nilai $Q_{\mathrm{c}}$ lebih besar dari $K_{\text {sp. }}$. Jawaban siswa yang kurang atau mendekati kriteria untuk kedua soal ini akan masuk ke dalam lima kategori lainnya di bawah "memahami konsep". Rincian deskripsi yang dijadikan panduan dalam pengkategorian pemahaman siswa dapat dilihat pada Tabel 3 dan Tabel 4 berikut ini.

Tabel 3. Kategori Pemahaman Siswa untuk soal $\mathrm{PbCl}_{2}$

\begin{tabular}{|l|l|}
\hline $\begin{array}{l}\text { Tingkat Pema- } \\
\text { haman }\end{array}$ & \multicolumn{1}{|c|}{ Deskripsi pemahaman } \\
\hline $\begin{array}{l}\text { Memahami } \\
\text { konsep }\end{array}$ & $\begin{array}{l}\text { Pernyataan prediksi benar, menyatakan dasar } \\
\text { prediksi adalah perbandingan } Q_{\mathrm{c}} \text { dengan } K_{\mathrm{sp}}, \\
\text { serta didasarkan pada hasil perhitungan yang } \\
\text { menunjukkan } Q_{\mathrm{c}}>K_{\mathrm{sp}} .\end{array}$ \\
\hline $\begin{array}{l}\text { Memahami } \\
\text { sebagian }\end{array}$ & $\begin{array}{l}\text { Pernyataan prediksi benar, didasarkan pada } \\
\text { hasil perhitungan yang menunjukkan } Q_{\mathrm{c}}>K_{\mathrm{sp}} .\end{array}$ \\
\hline $\begin{array}{l}\text { Memahami } \\
\text { sebagian } \\
\text { dengan mis- } \\
\text { konsepsi }\end{array}$ & $\begin{array}{l}\text { Pernyataan prediksi benar, didasarkan pada } \\
\text { hasil perbandingan dimana } Q_{\mathrm{c}}>K_{\mathrm{sp}} \text { tetapi } \\
\text { terdapat kesalahan substitusi nilai konsentrasi } \\
\text { molar atau persamaan untuk menghitung } Q_{\mathrm{c}} .\end{array}$ \\
\hline Miskonsepsi & $\begin{array}{l}\text { Prediksi benar, tetapi dasar dari prediksi } \\
\text { tersebut bukan perbandingan } Q_{\mathrm{c}} \text { dengan } K_{\mathrm{sp}} .\end{array}$ \\
\hline
\end{tabular}




\begin{tabular}{|l|l|}
\hline $\begin{array}{l}\text { Tidak me- } \\
\text { mahami }\end{array}$ & Prediksi terbentuknya endapan salah. \\
\hline $\begin{array}{l}\text { Tidak ada } \\
\text { respon }\end{array}$ & $\begin{array}{l}\text { Kosong; menuliskan "saya tidak tahu" atau } \\
\text { tidak menjawab sama sekali. }\end{array}$ \\
\hline
\end{tabular}

Tabel 4. Kategori Pemahaman Siswa Untuk Soal Urutan Garam Sulfat yang Duluan Mengendap

\begin{tabular}{|l|l|}
\hline $\begin{array}{l}\text { Tingkat } \\
\text { Pemahaman }\end{array}$ & \multicolumn{1}{|c|}{ Deskripsi pemahaman } \\
\hline $\begin{array}{l}\text { Memahami } \\
\text { konsep }\end{array}$ & $\begin{array}{l}\text { Urutan garam sulfat benar, dari yang paling awal } \\
\text { mengendap hingga yang paling akhir, dasar penen- } \\
\text { tuan urutan benar, terutama menyinggung } \\
\text { koesifien ion dalam reaksi setimbang dan konsen- } \\
\text { trasi semua garam sama. }\end{array}$ \\
\hline $\begin{array}{l}\text { Memahami } \\
\text { sebagian }\end{array}$ & $\begin{array}{l}\text { Urutan garam benar, penjelasan hanya } \\
\text { mengandung sebagian dari frasa penting dalam } \\
\text { kunci jawaban. }\end{array}$ \\
\hline $\begin{array}{l}\text { Memahami } \\
\text { sebagian } \\
\text { dengan } \\
\text { miskonsepsi }\end{array}$ & $\begin{array}{l}\text { Urutan benar, penjelasan mengandung sedikit } \\
\text { miskonsepsi, atau penjelasan benar tetapi ada } \\
\text { kesalahan dalam urutan garam. }\end{array}$ \\
\hline $\begin{array}{l}\text { Miskonsepsi } \\
\text { Tidak me- } \\
\text { mahami }\end{array}$ & $\begin{array}{l}\text { Urutan terbalik, penjelasan tidak sesuai konsep } \\
\text { Tidau mengurutkan garam sulfat berdasarkan } \\
\text { cepat atau lambatnya garam tersebut } \\
\text { mengendap. }\end{array}$ \\
\hline $\begin{array}{l}\text { Tidak ada } \\
\text { respon }\end{array}$ & $\begin{array}{l}\text { Kosong; menuliskan "saya tidak tahu" atau tidak } \\
\text { menjawab sama sekali. }\end{array}$ \\
\hline
\end{tabular}

Tingkat pemahaman siswa berdasarkan hasil analisis horizontal terhadap jawaban siswa dapat dilihat pada Diagram 1 berikut ini.

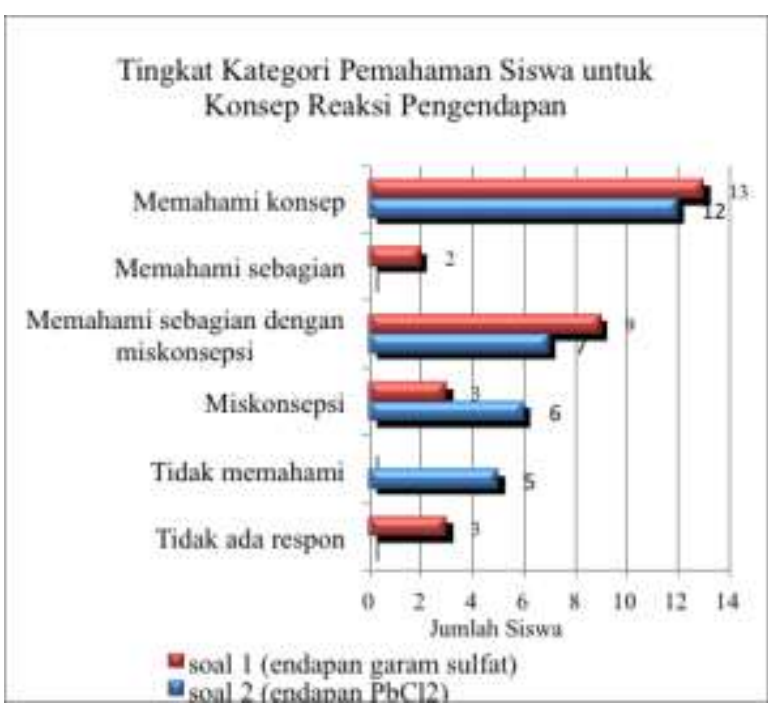

Diagram 1. Tingkat Kategori Pemahaman Siswa untuk Konsep Reaksi Pengendapan

Dari diagram 1 dapat dijelaskan bahwa kurang dari setengah subyek penelitian yang masuk ka-tegori memahami konsep, baik untuk soal 1 maupun soal 2. Meski mampu mengurutkan senyawa garam sulfat atau memprediksi pembentukan endapan dengan benar, peneliti tetap menemukan adanya kesalahan atau miskon sepsi dari jawaban sejumlah siswa.

Temuan menarik adalah: untuk soal 1 ada tiga siswa yang tidak menjawab, sementara untuk soal 2 tidak ada siswa yang tidak menjawab namun ada lima siswa yang masuk kategori tidak memahami. Keterbatasan waktu penelitian menyebabkan peneliti tidak berkesempatan untuk melakukan wawancara dengan siswa untuk mencari penjelasan dibalik temuan ini. Dugaan sementara, siswa mencoba menebak jawaban untuk soal 2 berdasarkan data dalam soal meski tebakan tersebut membawa mereka ke dalam kategori tidak memahami. Dasar dari dugaan ini adalah temuan bahwa dua dari tiga siswa yang tidak menjawab soal 1 termasuk ke dalam lima siswa yang masuk kategori "tidak memahami" pada soal 2. Untuk soal 2, endapan yang diprediksi hanya untuk satu senyawa yaitu $\mathrm{PbCl}_{2}$. Dari hasil ini, peneliti menduga siswa menggunakan data dalam soal atau instinc pribadi untuk memprediksi. Sementara untuk soal 1, tebakan demikian sulit dilakukan karena ada banyak senyawa yang harus dipertimbangkan. Tanpa pemahaman konsep yang benar, akan sulit bagi siswa untuk menjawab dengan benar.

Terkait dengan jawaban siswa yang mengandung kesalahan atau miskonsepsi, peneliti menjabarkan temuan tersebut dalam Tabel 4 berikut ini.

Tabel 5. Bentuk Kesalahan Siswa dalam Memprediksi Pembentukan Endapan Garam Sulfat Berdasarkan Nilai $K_{\text {sp. }}$.

\begin{tabular}{|c|c|}
\hline No. & Bentuk Kesalahan dan Contoh Jawaban Siswa \\
\hline \multirow[t]{2}{*}{1.} & Kesalahan menuliskan urutan senyawa \\
\hline & $\begin{array}{l}\text { - SR21 mengurutkan garam sulfatnya terbalik dari } \\
\text { tuntutan soal. } \\
\text { - } \mathrm{SU}_{8} \text { membuat kesalahan dalam urutan } \mathrm{HgSO}_{4} \\
\text { dan } \mathrm{SnSO}_{4}\end{array}$ \\
\hline \multirow[t]{2}{*}{2.} & $\begin{array}{l}\text { Alasan penentuan urutan tidak tepat/ mengandung } \\
\text { pernyataan yang salah }\end{array}$ \\
\hline & $\begin{array}{l}\text { - SR1 dan SR10: } \\
\text { "Yang pertama akan mengendap adalah } \mathrm{BaSO}_{4} \\
\text { karena terlalu basa karena menyebabkan larutan } \\
\text { tersebut sukar larut; yang kedua yaitu } \mathrm{PbSO}_{4} \text { ka- } \\
\text { rena } K_{\mathrm{sp}} \mathrm{PbSO}_{4} \text { memiliki } K_{\mathrm{sp}} \text { yang basa juga } \\
\text { (garam sukar larut); ketiga } \mathrm{HgSO}_{4} \text { karena } K_{\mathrm{sp}} \\
\text { nya tepat jenuh, keempat } \mathrm{SnSO}_{4} \text { karena } K_{\mathrm{sp} n y a} \\
\text { tepat jenuh, kelima CaSO } \mathrm{C}_{4} \text { karena } K_{\text {spnya asam, }} \text {, } \\
\text { jadi larutan tersebut akan semakin mudah larut". }\end{array}$ \\
\hline
\end{tabular}
lasnya

Melalui soal ini, pemahaman siswa yang diharapkan muncul adalah bahwa untuk senyawa-senyawa dengan perbandingan koefisien ion 
yang sama, semakin kecil harga $K_{\text {sp }}$ maka senyawa tersebut akan semakin mudah mengendap. Senyawa yang paling banyak ditemukan salah urutannya adalah $\mathrm{HgSO}_{4}\left(K_{\mathrm{sp}}=6,7 \times 10^{-7}\right)$ dan $\mathrm{SnSO}_{4}\left(K_{\mathrm{sp}}=2,5 \times 10^{-7}\right)$. Peneliti menduga kesalahan ini disebabkan kesalahan menginterpretasikan nilai $K_{\mathrm{sp}}$ yang memiliki bilangan pangkat negatif, sehingga $K_{\text {sp }} \mathrm{HgSO}_{4}$ dipahami lebih kecil dari $K_{\mathrm{sp}} \mathrm{SnSO}_{4}$ padahal sebaliknya.

Selain kesalahan mengurutkan senyawa, ditemukan pula alasan penentuan yang tidak sesuai dengan konsep. Pada contoh kesalahan kedua, siswa tersebut salah mengurutkan $\mathrm{SnSO}_{4}$ dan $\mathrm{HgSO}_{4}$, dan alasan penentuan yang diberikan tidak tepat. $\mathrm{BaSO}_{4}$ dipilih sebagai yang pertama mengendap karena terlalu basa, padahal tidak ada keterangan mengenai sifat asam dan basa dalam soal. Sifat basa ini juga menjadi dasar menentukan $\mathrm{PbSO}_{4}$ sebagai senyawa kedua yang mengendap. Dari jawaban siswa yang ada dalam tanda kurung "garam sukar larut", sepertinya siswa memahami garam dengan nilai $K_{\mathrm{sp}}$ sangat kecil sebagai garam yang bersifat basa, dan garam yang bersifat basa adalah garam yang sukar larut. Dengan demikian, garam dengan $K_{\mathrm{sp}}$ sangat kecil dipahami sebagai garam yang sukar larut atau mudah mengendap.

Tabel 6. Bentuk Kesalahan Siswa dalam Memprediksi Pembentukan $\mathrm{PbCl}_{2}$

\begin{tabular}{|c|c|}
\hline No. & Bentuk Kesalahan dan Contoh Jawaban Siswa \\
\hline \multirow[t]{8}{*}{1.} & Kesalahan dalam menentukan mol/ konsentrasi \\
\hline & $\begin{array}{l}\text { - SR25 dan SR17 membagi volum dengan mol } \\
\text { untuk mendapatkan suatu nilai yang disubsti- } \\
\text { tusikan ke dalam persamaan } K_{\mathrm{sp}} \text {. Hasilnya dinya- } \\
\text { takan sebagai } Q \text { c dan dibandingkan dengan } K_{\mathrm{sp}} \\
\mathrm{PbCl}_{2} \text { nilainya ternyata lebih besar }\end{array}$ \\
\hline & 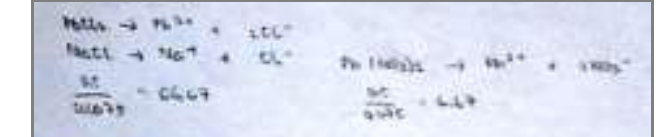 \\
\hline & 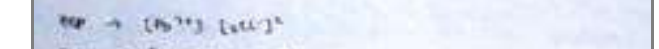 \\
\hline & $\approx \rightarrow[\cos 2][\cos ]$ \\
\hline & 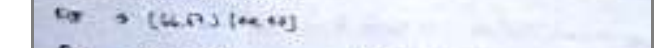 \\
\hline & At is ant \\
\hline & $Q_{E}>$ kp \\
\hline \multirow{3}{*}{2.} & \\
\hline & $(s)$ \\
\hline & $\begin{array}{l}\text { - SU7 mensubstitusikan konsentrasi dari masing- } \\
\text { masing ion sebagai nilai kelarutan ke dalam per- } \\
\text { samaan } K_{\mathrm{sp}} \mathrm{PbCl}_{2} \text { dimana }\left[\mathrm{Pb}^{2+}\right]=\mathrm{s} \text {, dan }\left[\mathrm{Cl}^{-}\right]= \\
\text {2s. }\end{array}$ \\
\hline
\end{tabular}

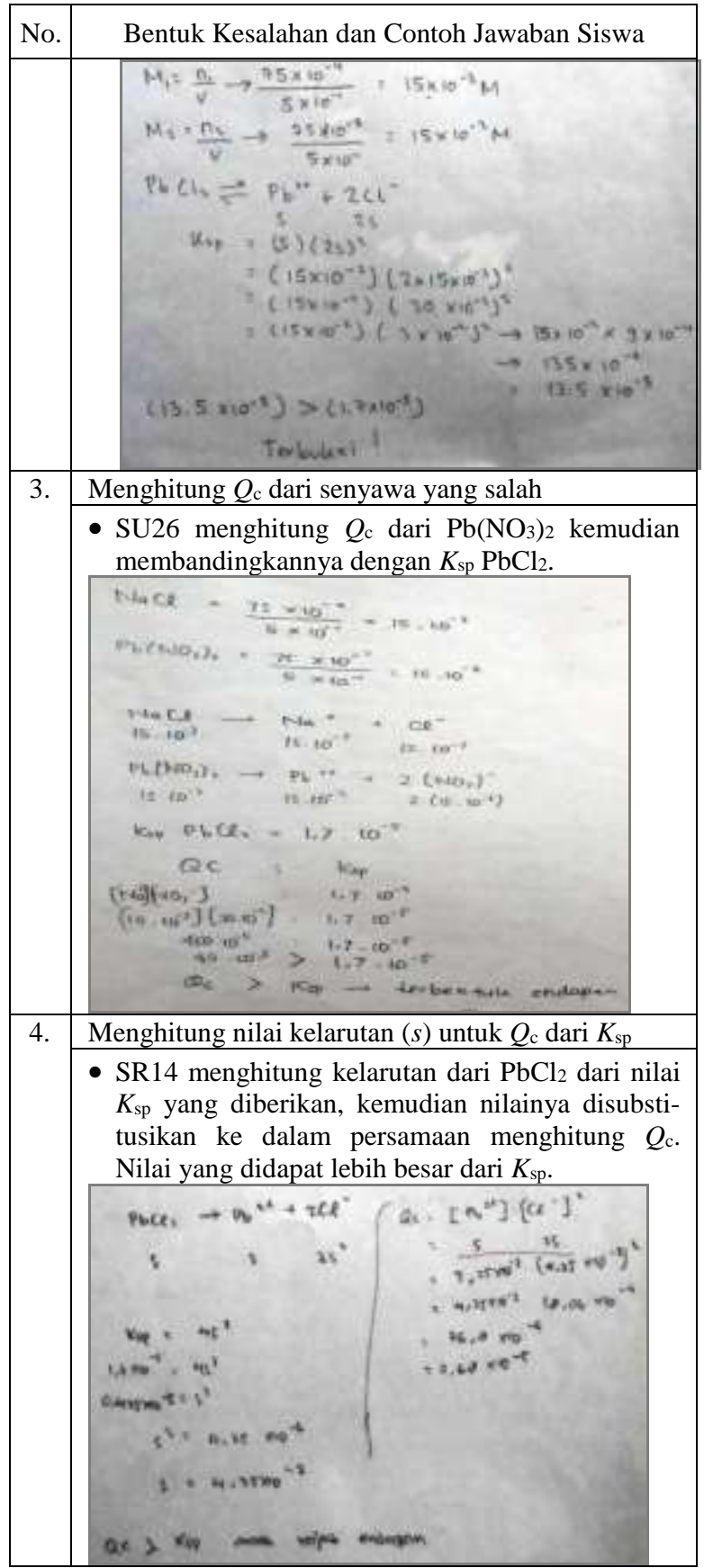

Ket: SR dan SU adalah label siswa untuk membedakan asal kelasnya

Bentuk kesalahan pertama pada Tabel 3 di atas disebabkan siswa tidak memahami bagaimana menghitung konsentrasi yang terlihat dari tindakan membagi volum dengan mol, dimana seharusnya mol yang dibagi dengan volum. Meski salah menentukan konsentrasi, siswa tersebut memahami bahwa prediksi endapan didasarkan pada nilai $Q_{\mathrm{c}}$ yang lebih besar dari $K_{\text {sp. }}$ Contoh bentuk kesalahan kedua disebabkan karena ketidakpahaman siswa tentang nilai yang harus dimasukkan ke dalam persamaan menghitung $Q_{\mathrm{c}}$. Siswa memasukkan 
nilai konsentrasi ion $\mathrm{Pb}^{2+}$ dan $\mathrm{Cl}^{-}$hasil perhitungannya ke dalam persamaan $K_{\mathrm{sp}}$ untuk $\mathrm{PbCl}_{2}$. Dengan kata lain, siswa menjadikan nilai konsetrasi masing-masing ion sebagai kelarutannya. Padahal, untuk kasus $\mathrm{PbCl}_{2}$ dalam soal ini, nilai konsentrasi hasil perhitungan tidak sama dengan kelarutan. Jadi, untuk bentuk kesalahan seperti ini, meski siswa memahami bahwa prediksi endapan didasarkan pada perbandingan nilai $K_{\mathrm{sp}}$ dan $Q_{\mathrm{c}}$, dan siswa mampu menuliskan persamaan $K_{\mathrm{sp}}$ untuk $\mathrm{PbCl}_{2}$ dengan benar, kurang tepatnya pemahaman siswa tentang kelarutan dan konsentrasi menyebabkan hasil perhitungan siswa salah.

Sedikit berbeda, contoh bentuk kesalahan ketiga disebabkan ketidakpahaman siswa terhadap penggunaan nilai $K_{\text {sp }}$ dan $Q_{\text {c }}$ untuk memprediksi pembentukan endapan. Lebih tepatnya, siswa tersebut tidak memahami nilai $K_{\mathrm{sp}}$ dan $Q_{\mathrm{c}}$ dari senyawa mana yang harus dibandingkan. Sebagai akibatnya adalah pada jawabannya, siswa tersebut menghitung nilai $Q_{\mathrm{c}}$ dari $\mathrm{Pb}(\mathrm{NO})_{3}$ kemudian membandingkannya dengan $K_{\mathrm{sp}} \mathrm{PbCl}_{2}$. Seharusnya, nilai $Q_{\mathrm{c}}$ dan $K_{\mathrm{sp}}$ yang dibandingkan adalah dari senyawa yang diprediksi mengendap, yaitu $\mathrm{PbCl}_{2}$.

Contoh bentuk kesalahan keempat disebabkan karena siswa tidak memahami perbedaan konsentrasi dan kelarutan, sehingga siswa tersebut menghitung kelarutan $\mathrm{PbCl}_{2}$ dari $K_{\text {sp }}$ yang diberikan kemudian nilainya disubstitusikan ke dalam persamaan untuk menghitung $Q_{\mathrm{c}}$. Jika kelarutan dihitung dari $K_{\mathrm{sp}}$, kemudian digunakan menghitung $Q_{c}$, hasilnya tentu akan sama. Namun, hasil perbandingan yang didapat siswa adalah nilai $Q_{\mathrm{c}}$ lebih besar dari $K_{\text {sp }}$. Ternyata, dari jawaban siswa ditemukan kesalahan dalam menyatakan kelarutan ion $\mathrm{Pb}^{2+}$ dan $\mathrm{Cl}^{-}$ dan mensubstitusikan nilai kelarutan ke dalam persamaan $Q_{\mathrm{c}}$. Siswa tersebut menyatakan kelarutan $\mathrm{Pb}^{2+}$ sebagai $s$ dan $\mathrm{Cl}$ - sebagai $2 s$, namun ia mensubstitusikan nilai kelarutan ke dalam persamaan $s$ dan $s^{2}$. Selain itu, nilai kelarutan yang diperoleh dari $K_{\text {sp }} \mathrm{PbCl}_{2}$ juga tidak benar karena kesalahan penarikan akar pangkat tiga. Kedua kesalahan inilah yang menyebabkan nilai $Q_{\mathrm{c}}$ yang ia peroleh lebih besar dari $K_{\mathrm{sp}}$.

\section{Proses Pembelajaran Konsep Reaksi Pengendapan}

Pembelajaran konsep Reaksi Pengendapan dilaksanakan pada pertemuan keempat me- lalui kegiatan praktikum. Siswa diminta membuat beberapa senyawa garam sukar larut melalui reaksi pengendapan dari dua larutan yang dicampurkan. Gambar 1 berikut ini menunjukkan langkah percobaan yang harus dilakukan siswa. Ilustrasi tersebut menunjukkan bahwa percobaannya cukup sederhana dan tidak membutuhkan waktu lama. Sebagaimana biasanya praktikum dilakukan di SMA, setelah percobaan siswa diminta menjawab beberapa pertanyaan dalam LKS.

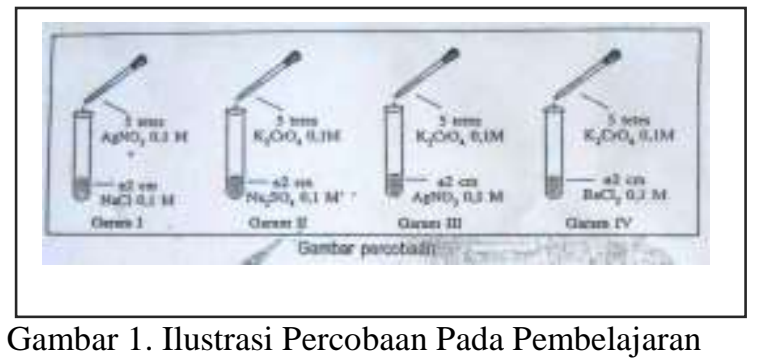
Konsep Reaksi Pengendapan

Berikut ini adalah kutipan dialog guru dan siswa saat menjelaskan konsep reaksi pengendapan di kelas.

Guru : "Sekarang, kapan terjadi reaksi pengendapan itu? Kan tadi ada larutan yang... Apa? Belum jenuh, tepat jenuh, dan lewat jenuh. Nah, kapan suatu larutan... garam itu mengendap? Kapan? Apa itu $Q_{c}$ ? Sama dengan...?"

Siswa : " $\underline{K}_{s p \ldots \ldots} \ldots$ (bersama-sama)

Guru : "Sama dengan $K_{\text {sp }}$ tapi apa? $K_{\text {sp }}$ itu apa? $K_{\text {sp }}$ itu adalah konsentrasi... Dah, ingat kalau dalam $\underline{K}_{\text {sp }}$ konsentrasi zat-zat dalam keadaan kesetimbangan sementara ini dalam keadaan tepat jenuh. Saat tepat jenuh, itu yang $K_{\mathrm{sp}}$. Sementara $Q_{c}$, konsentrasinya sama dengan keadaan dalam tetapan kesetimbangan, tapi bukan dalam keadaan tepat je...? Tepat jenuh. Jadi kalau $Q_{c}$ nya sama dengan $K_{s p_{2}}$ maka apa yang terjadi?"

Siswa: "Tepat jenuh..." (bersama-sama)

Guru : "Dah, hari Jumat kita sudah belajar mengenai garam-garam yang sukar larut. Nah, kapan, bisa terjadi pengendapan? Kapan garam tersebut mengendap? Misalnya garam dapur ini, kapan dia mengendap?"

SR14 : "Apabila larutannya sudah jenuh..." 
Guru : "Larutannya sudah jenuh. Jika konsentrasi zat yang ada dalam sistem kesetimbangan tadi sudah lebih besar dari jumlah maksimum ini, maka garam tersebut akan membentuk endapan. Nah, hasil kali konsentrasi zat yang dalam garam tadi yang melewati konsentrasi zat dalam keadaan tepat jenuh, itu kita sebut dengan $Q_{\mathrm{c}}$. $Q_{\mathrm{c}}$ ini rumusnya hampir sama dengan $K_{\mathrm{sp}}$. Cuma kalau $K_{\mathrm{sp}}$, konsentrasi zat ini adalah konsentrasi maksimum pada saat larutan tepat jenuh. Sementara, pada $Q_{\mathrm{c}}$, konsentrasi misalnya untuk $\mathrm{NaCl}$, konsentrasi $\mathrm{Na}^{+}$dan $\mathrm{Cl}^{-}$nya ini adalah konsentrasi zat tersebut dalam keadaan yang sudah lewat jenuh tadi, harganya. Jadi rumusnya, $Q_{\text {c }}$ dan $K_{\text {sp }}$ itu sama, cuma $K_{\text {sp }}$ konsentrasi zat pada saat sistem mencapai keadaan kesetim...bangan. Pada saat sistem mencapai keadaan kesetimbangan. tapi kalau $Q_{\mathrm{c}}$ konsentrasinya ini pada larutan, bisa jenuh pada larutan yang belum jenuh atau bisa juga pada larutan lewat je.. lewat jenuh. Jika harga $Q_{\text {c }}$ masih lebih kecil dari pada harga $K_{\text {sp }}$, maka ini kita sebut larutanya larutan yang belum jenuh. Sementara ketika saat $Q_{\mathrm{c}}$ sama dengan $K_{\mathrm{sp}}$, maka ini yang kita sebut dengan larutan tepat jenuh. tapi kalau $Q_{\mathrm{c}}$ sudah lebih besar dari $K_{\text {sp }}$, maka ini yang kita sebut larutan lewat jenuh. Jadi, kalau larutan lewat jenuh maka itu berarti sudah terbentuk endapan. Jadi kalau misalnya kta mau mengendapkan suatu zat, maka zat yang kita larutkan itu konsentrasinya harus lebih besar dari konsentrai ionionnya pada saat larutan tepat jenuh. Jadi kalau misalnya kita melarutkan suatu zat, garam atau zat yang sukar larut., kita sudah bisa meninjau sebelum kita melakukan percobaan apakah garam ini bisa menghasilkan endapan atau tidak."

Pada dasarnya, guru sudah menjelaskan dalam pembelajaran bahwa $Q_{\mathrm{c}}$ berbeda dari $K_{\mathrm{sp}}$, dan nilai konsentrasi yang disubstitusikan juga berbeda. Namun, dari kutipan proses pembelajaran tersebut, terdapat beberapa hal yang dapat membuat siswa kebingungan dalam mempred- iksi terbentuknya endapan. Pertama, pada awalnya siswa memahami bahwa rumus $K_{\text {sp }}$ dan $Q_{c}$ hampir sama, namun kemudian dikatakan sama. Pada dasarnya, rumus $Q_{\mathrm{c}}$ dan $K_{\mathrm{sp}}$ memang sama, yang membedakan adalah keadaan saat mengambil nilai konsentrasi untuk dimasukkan ke dalam persamaan untuk menghitung $Q_{\mathrm{c}}$ dan $K_{\text {sp }}$. Kedua, konsentrasi yang disubstitusikan ke dalam persamaan $K_{\mathrm{sp}}$ dan $Q_{\text {c. }}$. Dari proses pembelajaran, siswa memahami bahwa $K_{\text {sp }}$ adalah konsentrasi zat saat tepat jenuh, dan $Q_{\mathrm{c}}$ adalah konsentrasi zat saat setimbang. Padahal, konsentrasi zat saat tepat jenuh adalah konsentrasi zat saat setimbang. Seharusnya, $Q_{\mathrm{c}}$ adalah hasilkali konsentrasi zat selama reaksi berlangsung, bisa di awal, saat setimbang, atau akhir reaksi. Saat $Q_{\mathrm{c}}$ sama dengan harga $K_{\text {sp }}$, keadaan saat itu disebut tepat jenuh.

Dalam buku teks pembelajaran, konsep reaksi pengendapan disajikan dalam bentuk aplikasi konsep dalam materi Kelarutan dan Hasilkali Kelarutan, yaitu untuk pemisahan campuran melalui pengendapan. Dalam menjelaskan aplikasi tersebut, buku teks tidak memuat perbandingan nilai $Q_{\mathrm{c}}$ dengan $K_{\mathrm{sp}}$ sebagai dasar memprediksi endapan. Berikut ini adalah kutipan materi dari buku teks tersebut.

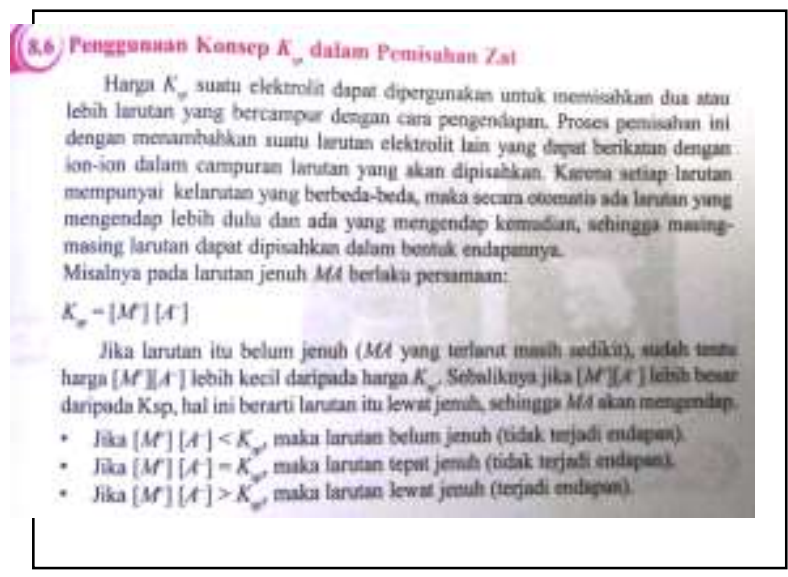

Gambar 2. Penerapan Konsep Kelarutan dan Hasilkali Kelarutan pada Reaksi Pengendapan dalam Buku Teks Siswa

Bentuk kesalahan (1) dan (2) pada Tabel 3 berkaitan dengan pemahaman siswa mengenai konsep kelarutan dan konsentrasi. Sementara bentuk kesalahan (3) dan (4) menunjukkan ketidakpahaman siswa mengenai konsep reaksi peng endapan itu sendiri. Berdasarkan proses pembelajaran yang terjadi, terlihat bahwa ketidakjelasan mengenai nilai konsentrasi yang di substitusikan ke dalam persamaan $K_{\mathrm{sp}}$ dan $Q_{\mathrm{c}}$ diduga menjadi penyebab siswa melakukan ben- 
tuk kesalahan (2), (3), dan (4). Sementara itu, bentuk kesalahan (1) berakar dari ketidakmampuan siswa membedakan konsep kelarutan dan konsentrasi.

\section{Upaya Guru untuk Meningkatan Pema- haman Siswa terhadap Konsep Reaksi Pengendapan}

Untuk mencegah siswa melakukan bentuk-bentuk kesalahan atau miskonsepsi dalam pembelajaran, terdapat beberapa hal dari proses pembelajaran yang dapat dilakukan.

Pertama, pembelajaran konsep reaksi pengendapan dilakukan melalui kegiatan percobaan pembuatan garam sukar larut dari campuran beberapa larutan. Setelah percobaan, siswa melengkapi LKS berisi soal penulisan persamaan reaksi pengendapan dan rumus kimia endapan, penulisan persamaan $K_{\mathrm{sp}}$ dan hubungan s dengan $K_{\text {sp }}$, serta perhitungan kelarutan senyawa dari data $K_{\text {sp }}$ dan konsentrasi pelarut yang diberikan. Menurut peneliti, agar sesuai dengan kompetensi yang ingin dicapai dari pembelajaran, LKS siswa sebaiknya mengandung pertanyaan yang meminta siswa memprediksi pembentukan endapan dari larutan yang dicampurkan, kemudian prediksi tersebut dibuktikan dengan percobaan. Sehingga, siswa memahami cara memprediksi pembentukan endapan tersebut baik dari segi kuantitatif dan kualitatif.

Kedua, proses pembelajaran perlu menekankan perbedaan yang jelas mengenai nilai konsentrasi yang disubstitusikan ke dalam persamaan $Q_{\mathrm{c}}$ dan $K_{\mathrm{sp}}$. Selain itu, perlu ditekankan juga bahwa nilai $Q_{\mathrm{c}}$ dan $K_{\mathrm{sp}}$ yang dibandingkan adalah nilai $Q_{\mathrm{c}}$ dan $K_{\mathrm{sp}}$ dari garam yang diprediksikan akan mengendap. Penekanan tersebut berkaitan dengan temuan dari jawaban siswa yang membandingkan $Q_{\mathrm{c}}$ satu senyawa dengan $K_{\text {sp }}$ senyawa lain.

\section{KESIMPULAN}

Bentuk kesalahan atau miskonsepsi yang ditemukan dari hasil analisis jawaban siswa terkait soal prediksi pembentukan endapan antara lain: 1) kesalahan menuliskan urutan senyawa; 2) alasan penentuan yang tidak tepat atau mengandung pernyataan yang salah; 3) kesalahan dalam menghitung mol; 4) kesalahan mensubstitusikan nilai kelarutan $(s) ; 5)$ menghitung nilai $Q_{\mathrm{c}}$ dari senyawa yang salah; dan 6) menghitung nilai kelarutan (s) untuk $Q_{\mathrm{c}}$ dari nilai $K_{\text {sp. }}$. Analisis transkripsi rekaman proses pembelajaran membawa peneliti pada dugaan penyebab munculnya bentuk-bentuk kesalahan pada jawaban siswa. Penyebab tersebut antara lain: ketidaksesuaian penjelasan terkait penerapan konsep kelarutan dan hasilkali kelarutan untuk memprediksi pembentukan endapan dalam buku teks siswa; soal-soal dalam LKS yang belum terlalu sesuai dengan indikator pencapaian kompetensi pembelajaran; kurangnya penekanan guru saat menjelaskan nilai konsentrasi dan kelarutan yang harus disubstitusikan dalam persamaan untuk menghitung nilai $Q_{\mathrm{c}}$ dan $K_{\text {sp. }}$. Dugaan penyebab ini dapat menjadi pertimbangan oleh guru untuk merumuskan skenario pembelajaran yang lebih baik untuk konsep reaksi pengendapan dimasa yang akan datang agar bentuk kesalahan dan miskonsepsi yang ditemukan ini tidak muncul kembali.

\section{DAFTAR PUSTAKA}

Abraham, M.R., Grzybowski, E.B., Renner, J.W., and Marek, E.A. (1992). "Understanding and Misunderstanding of Eight Graders of Five Chemistry Concepts Found in Textbooks". Journal of Research In Science Teaching. 29, (2) 105 -120 .

Basrowi dan Suwandi. (2008). Memahami Penelitian Kualitatif. Jakarta: Rineka Cipta.

Chang, R., Overby, J. (2008). General Chemistry: The Essential Concepts. $6^{\text {th }}$ Ed. New York: McGraw-Hill Companies.

Chiu, M. (2005). "A National Survey Of Students Conceptions In Chemistry In Taiwan". Chemical Education International. 6. (1). Paper based on the lecture presented at the 18th ICCE, Istanbul, Turkey, 3-8 August 2004

Gronlund, N.E. dan Linn, R.L. (1990). Measurement and Evaluation In Teaching. $6^{\text {th }}$ Ed. New York: Macmillan Publishing Company

Harris, D.C. (2010). Quantitative Chemical Analysis. $8^{\text {th }}$ Ed. United States of America: W.H. Freeman and Company.

Holbrook, J. (2005). "Making Chemistry Teaching Relevant". Chemical Education International. 6, (1).

Johnstone, A. H. (2000). "Teaching of Chemistry - Logical or Psychological?" Chemistry Education: Research and 
Practice in Europe. 1(1), 9 - 15. doi: 10.1039/A9RP90001B.

Kemendikbud. (2016). Peraturan Kementerian Pendidikan dan Kebudayaan No. 21 Tahun 2016 tentang Standar Isi. Jakarta: Kemendikbud

Nakhleh, M.B., Hinton, M.E. (1999). "Students' Microscopic, Macroscopic, and Symbolic Representation of Chemical Reactions". Chem. Educator, 4, 158 167. doi: 10.1007/s00897990325a.

Sheehan, M. (2010). Identification of Difficult Topics In The Teaching and Learning of Chemistry in Irish High Schools and The Development of An Intervention Programme To Target Some Of The Difficulties. Disertasi pada Department of Chemical and Environmental Science University of Umerick, Irlandia. Tidak Diterbitkan.

Wu, C. and Foos, J. (2008). "Making Chemistry Fun To Learn". Literacy Education And Computer Education Journal (LICEJ). 1, (1), 3-7 